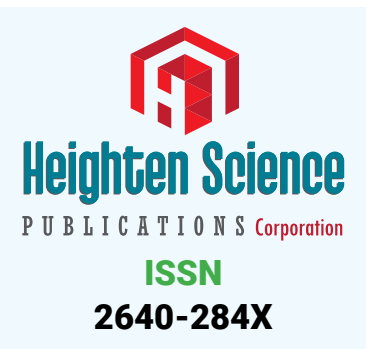

*Address for Correspondence: Dr. Ian James Martins, School of Medical Sciences, Edith Cowan University, Western Australia 6009, Australia, Tel: +61863042574; Email: i.martins@ecu.edu.au

Submitted: 24 January 2018

Approved: 30 January 2018

Published: 31 January 2018

Copyright: @ 2018 Martins IJ. This is an open access article distributed under the Creative Commons Attribution License, which permits unrestricted use, distribution, and reproduction in any medium, provided the original work is properly cited

Keywords: Neuroendocrine system; Metabolism; Adipose tissue; Liver; Mitphagy; NAFLD; Obesity; Apelin; Sirtuin 1; Nitric oxide; Autoimmune disease Caffeine; Cardiovascular disease; Curcumin; Cinnamon

Check for updates

\section{Editorial \\ Indian spices and Caffeine treatment for Obesity and Cardiovascular disease}

\author{
Ian James Martins ${ }^{1-3 *}$ \\ ${ }^{1}$ Centre of Excellence in Alzheimer's Disease Research and Care, Sarich Neuroscience \\ Research Institute, Edith Cowan University, Verdun Street, Nedlands, 6009, Western Australia, \\ Australia \\ ${ }^{2}$ School of Psychiatry and Clinical Neurosciences, the University of Western Australia, \\ Nedlands, 6009, Australia \\ ${ }^{3}$ McCusker Alzheimer's Research Foundation, Hollywood Medical Centre, 85 Monash Avenue, \\ Suite 22, Nedlands, 6009, Australia
}

\section{Editorial}

The global obesity epidemic that was previously reported [1,2] is now to worsen with obesity to double in 73 countries around the world [3,4]. Improving the health of obese individuals by dietary restriction, anti-obese foods and increased physical activity [1] has not reduced the global obesity epidemic. Obesity is linked to nonalcoholic fatty liver disease (NAFLD) [5,6] with complications relevant to the metabolic syndrome and cardiovascular disease [7]. Appetite control has become critical to endocrinology and metabolism with the apelinergic pathway and nuclear receptor Sirtuin 1 (Sirt 1) now connected to the endocrine system [8] and critical to metabolism. The apelin-Sirt 1 interaction involves nitric oxide (NO) [9] that is now considered as the defect [10] in the interaction between the peptide apelin and calorie sensitive gene Sirt 1 involved in NO imbalances in the adipose tissue, liver and the brain.

A model proposed involves the central co-ordination of the neuroendocrine system by the suprachiasmatic system in the hypothalamus with the adipose tissue and liver in the periphery [8]. The apelinergic pathway is linked to NO balance between the brain, adipose tissue and liver [10] with dietary composition (low calorie diets) and reduction of stress [8] essential to maintain the NO co-ordination of the neuroendocrine system between the brain and peripheral tissues. Nutrigenomic diets are now essential to activate Sirt 1 [11] involved in NO regulation that activates the adipose tissue-liver interaction for the prevention of NAFLD. The crosstalk between the adipose tissue and liver has become of major concern in various communities with adipocyte dysfunction linked to the acceleration of NAFLD [12]. Drugs that lower fat absorption and activate adipose tissue and liver Sirt 1 have been recommended for human use [13] but the use of other anti-obese drugs have raised concerns [14].

The composition of diets have now become important with adipogenesis a major disorder connected to NAFLD. The reports of obesity to become a pandemic is now related to accelerated aging with mitophagy [15] the major defect in NAFLD. The adipocyte and its transformation with relevance to apelin-Sirt 1 defects is related to autoimmune disease and linked to mitophagy and NAFLD [9,15-17].

Sirt 1 via peroxisome proliferator-activated receptor gamma coactivator 1-alpha releases apelin [18] with Sirt 1/ peroxisome proliferator-activated receptor gamma 
coactivator 1-alpha linked to mitochondrial biogenesis [11]. Sirt 1 mutations have been reported in obesity, diabetes, cardiovascular disease and autoimmune disease [2,19$21]$. Sirt 1 is the heat shock gene $[22,23]$ with its repression involved with dysregulation of heat shock protein 70 (HSP70), natural killer cell activation and mitophagy [24]. Defective adipose tissue-liver interaction has been treated with caffeine to prevent mitophagy [25,26] linked to adipocyte dysfunction and reversal of NAFLD [27]. Nutrition therapy that allows co-ordination between the brain, adipose tissue and liver activates the apelinergic-Sirt 1 interaction essential for hepatic caffeine metabolism and caffeine's critical role as modulation of Sirt 1 in the brain [28] important to the prevention of obesity.

The health promoting benefits and protective role of Indian spices [29] have been reported in obesity and NAFLD with their role as an antioxidant and antimicrobial agent important to the maintenance of the adipose tissue-liver interaction. Identification of spices such as five commonly used dietary spices include saffron, curcumin, pepper family, zingiber and cinnamon to inhibit amyloid beta aggregation. The curry spice curcumin has been extensively studied in animal models to reduce amyloid pathology with beneficial effects on the prevention of neurodegeneration in man. Curcumin (Figure 1) has been used in various studies to inhibit adipogenesis and decrease adipose tissue mass [30-33]. In the liver curcumin has been shown to stabilize or reverse NAFLD [3436] but in specific controls curcumin has been shown to increase liver enzymes in short term studies. Indian spices now as novel therapeutic agents are potent in scavenging of NO [37] with relevance to apelin-Sirt 1 neuroendocrine regulation of NO balance. Curcumin has potent effects on NO synthase [38,39] with regulation of Sirt 1 control of NO synthase in endothelial cell in the liver and heart [8] (Figure 1). Curcumin is a potent inducer of the heat shock response $[40,41]$ with complete interference of the heat shock gene Sirt 1 regulation of HSP 70. Low dose curcumin ingestion is indicated with other Indian spice consumption and their clearance from the body is poorly understood [29] with higher dose curcumin involved with increased HSPs associated with amyloid beta aggregation (Figure 1) induced toxicity [40-42].

Cinnamon has now been reported to activate the adipose tissue-liver interaction with cinnamon effects on increased adipocyte lipid and glucose metabolism [43-45]. In the liver cinnamon has been used to stabilize NAFLD [46-48] with its important role as a Sirt 1 activator [29] connected to insulin therapy [49] and its maintenance of the adipose-tissue liver interaction. Consumption of spice intake and its quantification (mg/day) in man [29] vary considerably between countries with cinnamon Sirt 1 activation related to curcumin content with higher doses of curcumin relevant as a Sirt 1 inhibitor. Consumption of Indian spices need to be carefully controlled to avoid induction of obesity by complete nullification of caffeine's co-ordination of the neuroendocrine system by dysregulation of the brain, adipose tissue and liver interaction. Caffeine and its metabolism is critical to cardiovascular disease [50-52] with Indian spice intake (mg/day) now important with relevance to

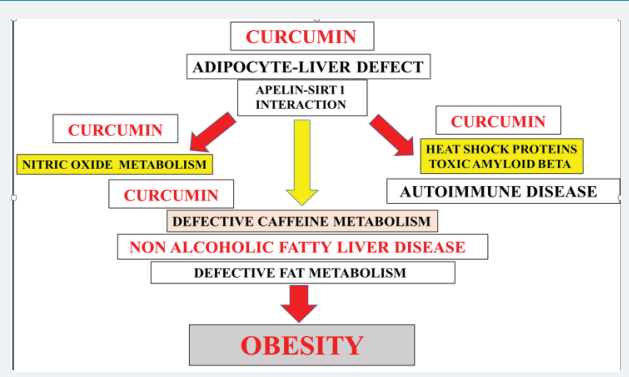

Figure 1: Appetite control is critical to endocrinology and metabolism with apelin-Sirt 1 interaction connected to the adipose-tissue interaction. Endocrine therapeutics that involve the apelin-Sirt 1 interaction and mitochondrial biogenesis are essential to reverse adipocyte dysfunction and the induction of NAFLD. Caffeine and Indian spices are involved with reversal of adipocyte dysfunction and NAFLD. Curcumin at higher doses should be carefully controlled to avoid NO imbalance connected to elevate HSPs with induction of autoimmune and chronic diseases. 
interference with caffeine's therapeutic properties in man and various species. Delayed caffeine clearance leads to interference with caffeine's beneficial effect on adipogenesis with increased transport to the brain relevant to mitochondrial induced apoptosis and the induction of Type 3 diabetes [26-28].

\section{Conclusion}

The global obesity epidemic that now affects many countries in the world has not improved in spite of dietary restriction, anti-obese foods and increased physical activity. The neuroendocrine system in many obese individuals is defective with an adipose tissue-liver defect that induces NAFLD and cardiovascular disease. Appetite control to reverse NAFLD and obesity has not been successful with revision of dietary composition that may allow activation of the adipose tissue-liver interaction. Indian spices are important to the adipose-tissue interaction but Indian spice intake should be carefully controlled to avoid curcumin toxicity (apelin-Sirt 1 inhibition) associated with defective fat and caffeine metabolism and associated with the induction of autoimmune and neuroendocrine disease.

\section{Acknowledgements}

This work was supported by grants from Edith Cowan University, the McCusker Alzheimer's Research Foundation and the National Health and Medical Research Council.

\section{References}

1. Martins IJ. Appetite dysregulation and obesity in Western Countries. LAP LAMBERT Academic Publishing. 2013. Ref.: https://goo.gl/9Q9tnW

2. Martins IJ. Induction of NAFLD with Increased Risk of Obesity and Chronic Diseases in Developed Countries. OJEM Diseases. 2014; 4: 90-110. Ref.: https://goo.gl/uHz7H6

3. An R, Ji M, Zhang S. Global warming and obesity: a systematic review. Obes Rev. 2018; 19: 150-163. Ref.: https://goo.gl/i9GpEv

4. Friedrich MJ. Global Obesity Epidemic Worsening. JAMA. 2017;318:603. Ref.: https://goo.gl/79iEGw

5. Fabbrini E, Sullivan S, Klein S. Obesity and non-alcoholic fatty liver disease: biochemical, metabolic, and clinical implications. Hepatology. 2010; 51: 679-689. Ref.: https://goo.gl/ebJjFZ

6. Dietrich $P$, Hellerbrand $C$. Non-alcoholic fatty liver disease, obesity and the metabolic syndrome. Best Pract Res Clin Gastroenterol. 2014; 28: 637-653. Ref.: https://goo.gl/ecCzVn

7. Kim SH, Després JP, Koh KK. Obesity and cardiovascular disease: friend or foe? Eur Heart J. 2016; 37: 3560-3568. Ref.: https://goo.gl/4ZjohT

8. Martins IJ. Nutritional diets accelerate amyloid beta metabolism and prevent the induction of chronic diseases and Alzheimer's disease. J Endocrinol and Metab. Photon. 2015; 1-48.

9. Martins IJ. Apelin and Sirtuin 1 dysregulation induce Endocrine and Metabolic Disorders in Chronic disease. GJEM. 2017; 1:1. Ref.: https://goo.gl/Z3TmLM

10. Martins IJ. Apelinergic System Defects with Relevance to Mental Disorders in Diabetes. World J Psychiatry Ment Health Res. 2017; 1: 1001. Ref.: https://goo.gl/q3yoRr

11. Martins IJ. Unhealthy Nutrigenomic Diets Accelerate NAFLD and Adiposity in Global communities. J Mol Genet Med. 2015; 9: 1-8. Ref.: https://goo.gl/mWnRMX

12. Qureshi K, Abrams GA. Metabolic liver disease of obesity and role of adipose tissue in the pathogenesis of nonalcoholic fatty liver disease. World J Gastroenterol. 2007; 13: 3540-3553. Ref.: https://goo.gl/56N5AG

13. Martins IJ. Avasimibe and Sirt 1 Activators Reverse NAFLD and Obesity. Nov Appro Drug Des Dev. $2017 ; 1: 1-2$

14. Adan RA. Mechanisms underlying current and future anti-obesity drugs. Trends Neurosci. 2013; 36 : 133-40. Ref.: https://goo.gl/1n2Ha4 
15. García-Ruiz C, Baulies A, Mari M, García-Rovés PM, Fernandez-Checa JC. Mitochondrial dysfunction in non-alcoholic fatty liver disease and insulin resistance: cause or consequence? Free Radic Res. 2013; 47: 854-868. Ref.: https://goo.gl/iwfFy7

16. Martins IJ. Defective Interplay between Adipose Tissue and Immune System Induces Non Alcoholic Fatty Liver Disease. Updates Nutr Disorders Ther. 2017; 1: 3.1. Ref.: https://goo.gl/YQSnyd

17. Martins IJ. Autoimmune disease and mitochondrial dysfunction in chronic diseases. Res Chron Dis. 2017; 1: 10-12. Ref.: https://goo.gl/LXak5D

18. Mazzucotelli A, Ribet C, Castan-Laurell I, Daviaud D, Guigné C, et al. The transcriptional co-activator PGC-1alpha up regulates apelin in human and mouse adipocytes. Regul Pept. 2008; 150: 33-37. Ref.: https://goo.gl/rJtdLa

19. Kilic U, Gok O, Bacaksiz A, Izmirli M' Elibol-Can B, et al. SIRT1 gene polymorphisms affect the protein expression in cardiovascular diseases. PLoS One. 2014; 9: 90428. Ref.: https://goo.gl/3Y8B9Y

20. Biason-Lauber A, Böni-Schnetzler M, Hubbard BP, Bouzakri K, Brunner A, et al. Identification of a SIRT1 Mutation in a Family with Type 1 Diabetes. Cell Metab. 2013; 17: 448-455. Ref.: https://goo.gl/xjz2Qm

21. Hughes JW, Herold KC. Novel SIRT1 Mutation Linked to Autoimmune Diabetes in Humans. Cel Metab. 2013; 17: 311-312. Ref.: https://goo.gl/NQ5rtv

22. Martins IJ. Type 3 diabetes with links to NAFLD and Other Chronic Diseases in the Western World Int J Diab and Metab Disord. 2016; 1: 1-5. Ref.: https://goo.gl/hGqXFe

23. Martins IJ. Heat shock gene Sirtuin 1 regulates post-prandial lipid metabolism with relevance to nutrition and appetite regulation in diabetes. Int J Diab Clin Diagn. 2016; 3: 1-3. Ref.: https://goo.gl/WdzCgC

24. Martins IJ. Regulation of Core Body Temperature and the Immune System Determines Species Longevity. Curr Updates Gerontol. 2017; 1: 6. Ref.: https://goo.gl/y3tCqE

25. Martins IJ. Caffeine Consumption and Induction of Obesity in the Developed World. Ann Obes Disord. 2017; 2: 1018. https://goo.gl/km1Unh

26. Martins IJ. Nutrition Therapy Regulates Caffeine Metabolism with Relevance to NAFLD and Induction of Type 3 Diabetes. J Diabetes Metab Disord. 2017; 4: 019. Ref.: https://goo.gl/ukJA55

27. Martins IJ. Caffeine with Links to NAFLD and Accelerated Brain Aging. In Tech Open. 2017. Ref.: https://goo.gl/8dZsGD

28. Martins IJ. Caffeine consumption with Relevance to Type 3 diabetes and accelerated brain aging Res Reveiws: Neurosci. 2016; 1: 1-5. Ref.: https://goo.gl/qbUzY8

29. Martins IJ. Indian Spices and Unhealthy Diets interfere with Drug Therapy in Diabetes and Neurodegenerative Diseases. Nov Appro Drug Des Dev. 2018; 3: 1-4. Ref.: https://goo.gl/H5YZN4

30. Ejaz A, Wu D, Kwan P, Meydani M. Curcumin inhibits adipogenesis in 3T3-L1 adipocytes and angiogenesis and obesity in C57/BL mice. J Nutr. 2009; 139: 919-925. Ref.: https://goo.gl/XspCuq

31. Teich T, Pivovarov JA, Porras DP, Dunford EC, Riddell MC. Curcumin limits weight gain, adipose tissue growth, and glucose intolerance following the cessation of exercise and caloric restriction in rats. J Appl Physiol (1985). 2017; 123: 1625-1634. Ref.: https://goo.gl/djjGKY

32. Wang S, Wang X, Ye Z, Xu C, Zhang M, et al. Curcumin promotes browning of white adipose tissue in a norepinephrine-dependent way. Biochem Biophys Res Commun. 2015; 466: 247-253. Ref.: https://goo.gl/SuiirT

33. Bradford PG. Curcumin and obesity. Biofactors. 2013; 39: 78-87. Ref.: https://goo.gl/wkqhdv

34. Inzaugarat ME, De Matteo E, Baz P, Lucero D, García CC, et al. New evidence for the therapeutic potential of curcumin to treat nonalcoholic fatty liver disease in humans. PLoS ONE. 2017; 12: e0172900. Ref.: https://goo.gl/C5CdXU

35. Panahi $Y$, Kianpour $P$, Mohtashami $R$, Jafari $R$, Simental-Mendía LE, et al. Efficacy and Safety of Phytosomal Curcumin in Non-Alcoholic Fatty Liver Disease: A Randomized Controlled Trial. Drug Res (Stuttg). 2017; 67: 244-251. Ref.: https://goo.gl/QzbkiS

36. Rahmani S, Asgary S, Askari G, Keshvari M, Hatamipour M, et al. Treatment of Non-alcoholic Fatty Liver Disease with Curcumin: A Randomized Placebo-controlled Trial. Phytother Res. 2016; 30: 1540 1548. Ref.: https://goo.gl/oBQ7j7

37. Baliga MS, Jagetia GC, Rao SK, Babu K. Evaluation of nitric oxide scavenging activity of certain spices in vitro: a preliminary study. Nahrung. 2003; 47: 261-264. Ref.: https://goo.gl/97anfL 
38. Kalaivani P, Saranya RB, Ramakrishnan G, Ranju V, Sathiya S, et al. Cuminum cyminum, a dietary spice, attenuates hypertension via endothelial nitric oxide synthase and NO pathway in renovascular hypertensive rats. Clin Exp Hypertens. 2013; 35: 534-542. Ref.: https://goo.gl/R5V2P9

39. Nakatake R, Hishikawa $H$, Matsuhima $H$, Nakamura $Y$, Ishizaki $M$, et al. Curcumin protects liver inflammation by suppressing expression of inducible nitric oxide synthase in primary cultured rat hepatocytes. Functional Foods in Health and Disease. 2017; 7: 716-734. Ref.: https://goo.gl/CyxUaA

40. Calabrese V, Scapagnini G, Colombrita C, Ravagna A, Pennisi G, et al. Redox regulation of heat shock protein expression in aging and neurodegenerative disorders associated with oxidative stress: a nutritional approach. Amino Acids. 2003; 25: 437-444. Ref.: https://goo.gl/kZ3LvS

41. Mait $P$, Manna J. Activation of Heat Shock Proteins by Nanocurcumin to Prevent Neurodegenerative Diseases. Brain Disord Ther. 2014; 3:139. Ref.: https://goo.gl/vSsgkU

42. Martins IJ. Calorie Sensitive Anti-Aging Gene Regulates Hepatic Amyloid Beta Clearance in Diabetes and Neurodegenerative Diseases. EC Nutrition ECO. 2017; 01: 30-32. Ref.: https://goo.gl/FswPeB

43. Shatwan IA, Ahmed LA, Badkook MM. Effect of barley flour, crude cinnamon, and their combination on glycemia, dyslipidemia, and adipose tissue hormones in type 2 diabetic rats. J Med Food. 2013; 16: 656-662. Ref.: https://goo.gl/uvZt6j

44. Lopes BP, Gaique TG, Souza LL, Paula GS, Kluck GE, et al. Cinnamon extract improves the body composition and attenuates lipogenic processes in the liver and adipose tissue of rats. Food Funct. 2015; 6: 3257-3265. Ref.: https://goo.gl/5bCMBm

45. Kwan HY, Wu J, Su T, Chao X-C, Liu B, et al. Cinnamon induces browning in subcutaneous adipocytes. Scientific Reports. 2017; 7: 2447. Ref.: https://goo.gl/NGzgYy

46. Askari F, Rashidkhani B, Hekmatdoost A. Cinnamon may have therapeutic benefits on lipid profile, liver enzymes, insulin resistance, and high-sensitivity C-reactive protein in nonalcoholic fatty liver disease patients. Nutr Res. 2014; 34: 143-148. Ref.: https://goo.gl/hCkdx7

47. Hekmatdoost A. Prevention of Nonalcoholic Fatty Liver Disease (NAFLD) Progression to Nonalcoholic Steatohepatitis (NASH) by Modification of Lifestyle and Dietary Supplements. J Clin Nutr Diet. 2016; 2: 2. Ref.: https://goo.gl/rRi7VN

48. Eslamparast $\mathrm{T}$, Eghtesad S, Poustchi $\mathrm{H}$, Hekmatdoost A. Recent advances in dietary supplementation, in treating non-alcoholic fatty liver disease. World J Hepatol. 2015; 7: 204-212. Ref.: https://goo.gl/C6dmCa

49. Martins IJ. Insulin Therapy Inactivation is connected to NAFLD and Diabetes Severity Index. J Diab Clin Stud. 2017; 1: 001-003. Ref.: https://goo.gl/zXAMW3

50. Wilson PW, Bloom HL. Caffeine Consumption and Cardiovascular Risks: Little Cause for Concern. J Am Heart Assoc. 2016; 5: 003089. Ref.: https://goo.gl/mQymj7

51. Ding M, Bhupathiraju SN, Satija A, van Dam RM, Hu FB. Long-term coffee consumption and risk of cardiovascular disease: a systematic review and a dose-response meta-analysis of prospective cohort studies. Circulation. 2014; 129: 643-659. Ref.: https://goo.gl/eY1FgP

52. Martins IJ. Genomic Medicine and Acute Cardiovascular Disease Progression. Res Chron Dis. 2018. 